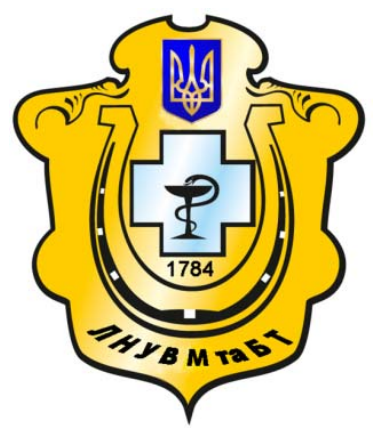

Науковий вісник Львівського національного університету ветеринарної медицини та біотехнологій імені С.3. Гжицького

Scientific Messenger of Lviv National University of Veterinary Medicine and Biotechnologies named after S.Z. Gzhytskyj

doi:10.15421/nvlvet7515

ISSN 2519-268X print

ISSN 2518-1327 online

$\underline{\text { http://nvlvet.com.ua/ }}$

УДК 637.54'65;637.525; 637.5.072

\title{
Дослідження ефективності використання бактеріальних препаратів на якісні характеристики делікатесних виробів
}

\author{
Т.А. Крижська \\ kryzhska@meta.ua
}

Сумський національний аграрний університет, вул. Г. Кондратьєва, 160, Суми, 40021, Украӥна

Досліджено упродовж визрівання фізико-хімічні, біохімічні та мікробіологічні характеристики делікатесного продукту з м'яса птииі, виготовленого зі застосуванням бактеріального препарату та нетрадииійних інгредієнтів рецептури. У статті показано, щуо корисна мікрофлора бактеріального препарату, який містить композицію бактеріальних итамів, позитивно впливає на сировину - філе курчат-бройлерів, в якому відбувається зміна не лише фізико-хімічних, а головне біохімічних показників. Перетворення вільних амінокислот і летких жирних кислот не тільки характеризує біологічну цінність продукту, а насамперед, обумовлює його смак і аромат. Доказом, є більш високий (до 30\%) вміст вільних амінокислот як в якісному, так $і$ в кількісному складі, порівняно з контролем. Показано, що в продукті з бактеріальним препаратом на кінцеву добу ферментування вміст летких жирних кислот на 11,6\% був вищим, ніж у контролі. Ефективність використання у продукті бактеріального препарату підтверджена і результатами мікробіологічних досліджень, за яких дослідний продукт був готовий на 3 доби раніше, ніж контроль. Отже, доведено, щэо використання бактеріального препарату змінюе інтенсивність та спрямованість процесу визрівання продукту, надає та формує специфічні смакоароматичні властивості та забезпечує продукту гарантовану якість.

Ключові слова: делікатеси, сиров'ялені продукти, рН, молочна кислота, білок, волога, бактеріальні препарати, м'ясо птиці, амінокислоти, леткі жирні кислоти.

\section{Исследование эффективности использования бактериальных препаратов на качественные характеристики деликатесных изделий}

\author{
Т.А. Крыжская \\ kryzhska@meta.ua
}

Сумской национальный аграрный университет, ул. Г. Кондратьева, 160, Сумьl, 40021, Украина

В процессе созревания исследованы физико-химические, биохимические и микробиологические характеристики деликатесного продукта из мяса птицы, изготовленного с применением бактериального препарата и нетрадиционных ингредиентов рецептуры. В статье показано, что полезная микрофлора препарата, который содержит композицию бактериальных штаммов, положительно влияет на сырье - филе иыплят-бройлеров. В нем происходит изменение не только физико-химических, а главное - биохимических показателей. Превращение свободных аминокислот и летучих жирных кислот не только характеризует биологическую иенность продукта, а прежде всего обусловливает его вкус и аромат. Доказательством является более высокое (до 30\%) содержание свободных аминокислот как в качественном, так и в количественном составе, по сравнению с контролем. Показано, что в продукте с препаратом в конце процесса ферментачии содержание летучих жирных кислот на 11,6\% было выше, чем в контроле. Эффективность использования в продукте бакпрепарата подтверждена и результатами микробиологических исследований, при которых опытный продукт был готов на 3 суток раньще, чем контроль. Доказано, что использование бакпрепарата влияет на

Citation:

Kryzhska, T. (2017). Research of efficiency of use of bacterial preparations on the quality characteristics of delicatessen products. Scientific Messenger LNUVMBT named after S.Z. Gzhytskyj, 19(75), 76-80. 
интенсивность и направленность проиесса созревания продукта, формирует спечифические вкусо-ароматические свойства и обеспечивает продукту гарантированное качество.

Ключевые слова: деликатесы, сыровяленые продукты, рН, молочная кислота, белок, влага, бактериальные препараты, мясо птиць, аминокислоты, летучие жирные кислоты.

\title{
Research of efficiency of use of bacterial preparations on the quality characteristics of delicatessen products
}

\author{
T. Kryzhska \\ kryzhska@meta.ua \\ Sumy National Agrarian University, \\ G. Kondratiieva Str. 160, Sumy, 40021, Ukraine
}

\begin{abstract}
Researched during the maturation of physical-chemical, biochemical and microbiological characteristics delicacy of poultry products produced with the use of bacterial preparation «LRR» non-traditional ingredients and recipes. The article shows that the bacterial microflora useful drug «LRR» containing composition of bacterial strains a positive impact on raw poultry - fillet of broiler chickens. In breast broiler chickens is a change, not just physical, chemical, and most importantly - biochemical parameters. The conversion of free amino acids and volatile fatty acids not only characterizes the biological value of the product, and above all, determines its taste and aroma. The proof is higher (30\%) of product research content of free amino acids, both in qualitative and quantitative composition compared with the control product. A product of bacterial preparation «LRR» dominant among the essential amino acids are valine, isoleucine, leucine, lysine, phenylalanine, and among replacement - aspartic and glutamic acid and alanine in relation to the reference sample. It is shown that the product of bacterial preparation «LRR» on the final day fermentation, the content of volatile fatty acids was $11.6 \%$ higher than the reference product. Efficiency in the product of bacterial preparation «LRR» and confirmed the results of microbiological studies. Which resulted, in lack of product research koliform observed three days earlier than the control product. The results of the proved that the use of bacterial preparation «LRR» changes the intensity and direction of the process of maturing the product, and provides specific forms taste aromatic properties and provides guaranteed product quality.
\end{abstract}

Key words: Delicacies, raw foods, $\mathrm{pH}$, lactic acid, protein, moisture, bacterial preparations, poultry meat, amino acids, volatile fatty acids.

\section{Вступ}

Останнім часом м'ясо птиці, що має порівняно низьку вартість при високій біологічній цінності, все частіше використовується для розширення асортименту м'ясної продукції. На сьогодні дедалі більшої популярності у споживачів набувають делікатесні м'ясні продукти. Організація процесу виробництва делікатесних сиров'ялених цільном'язових виробів із м'яса птиці базується на використанні правильно підібраних бактеріальних препаратів, інгредієнтів рецептури, раціональних технологічних режимів обробки м'ясної сировини (яка під час проведення технологічного процесу вимагає до себе особливого підходу). В результаті дотримання цих вимог готовий продукт 3 м'яса птиці має гарантовану якість. Метою роботи було дослідження якісних характеристик продукту під впливом функціонування бакпрепаратів та інгредієнтів рецептури упродовж процесу виготовлення делікатесних виробів.

\section{Матеріали та методи дослідження}

Сировиною слугувало охолоджене філе курчатбройлерів. У дослідному зразку для ферментування сировини застосовували бактеріальний препарат «ЛРP» (TU U 15.5-00419880-101-2010). Бакпрепарат вносили на етапі соління сировини у кількості 0,3\% від об'єму сировини, що відповідає концентрації не менше $10^{6}$ КУО на 1 г сировини. Така кількість культури за даними останніх досліджень є гарантом якісних показників готових продуктів з урахуванням мік- робного забруднення м'яса (Aro-Aro et al., 2010). Філе курчат-бройлерів готували за рецептурою - згідно 3 ТУ У 15.1-00419880-095:2008 «Продукти із м'яса птиці сирокопчені та сиров'ялені. Технічні умови». Ферментування сировини вели у кліматичній камері за параметрами, що регламентуються технологією продукту: температура від $(22 \pm 1){ }^{\circ} \mathrm{C}$ до $(12 \pm 1){ }^{\circ} \mathrm{C}$, відносна вологість повітря від $(90 \pm 1) \%$ до $(76 \pm 1) \%$ та швидкість руху повітря не більше $0,5 \mathrm{~m} / \mathrm{c}$. Загальна тривалість технологічного процесу - 12-15 діб.

Одержані зразки продукту аналізували за фізикохімічними, біохімічними та мікробіологічними показниками: вміст вологи - стандартним методом сушіння за ДСТУ ISO 1442:2005; кислотність - потенціометрично (Antipova et al., 2001). Молочну кислоту - фотометрично, методом кольорової реакції $з$ вератролом (Antipova et al., 2001). Амінокислотний склад зразків досліджували на аналізаторі «Biotronik LC 2000». Склад летких жирних кислот - методом газорідинної хроматографії на приладі «Купол-55». Кількість молочнокислих бактерій визначали згідно з ГОСТ 10444.11-89; кількість життєздатних клітин мікрококу в 1 г продукту - висівом відповідних десятикратних розведень у стерильному фізіологічному розчині на м'ясо-пептоному агарі з $5 \% \mathrm{NaCl}$; вміст БГКП - за ГОСТ 7702.2.2-93.

\section{Результати та їх обговорення}

Встановлено, що в процесі виробництва в усіх зразках відбувалася зміна хімічного складу, це було пов'язане зі зменшенням кількісного вмісту вологи 
(рис. 1) і збільшення сухих речовин - білка, жиру, золи. На початку процесу кількість вологи змінювалась за рахунок обробки сировини гігроскопічними речовинами, перш за все кухонною сіллю, а також інгредієнтами солильної суміші.

Так, в контролі кількість вологи знизилась на 5,2\%, в дослідному зразку на 7,0\% порівняно з вихідною сировиною. Слід зазначити, що найбільш інтенсивне зневоднення спостерігали на 5 добу сушіння. На 11 добу вміст вологи в дослідному зразку був нижчим на 9,3\%, ніж у контрольному. Наявність в рецептурі бакпрепарату вплинула на кінцевий вміст вологи в продукті.

Необхідний рівень вологи - не більше 40\%, на 11 добу сушіння, мав лише дослідний зразок, тимчасом як в контролі цей рівень був досягнутий на 14 добу. Різницю в 3 доби сушіння між зразками можна пояснити біохімічною активністю доданого бактеріального препарату.

Встановлено, що мікрофлора бактеріального препарату сприяла специфічній трансформації м'ясної сировини. На рисунку 2 показаний рівень молочної кислоти в готових продуктах. Ферментацію м'ясної сировини з використанням досліджуваного бакпрепарату обумовлювало підвищення концентрації молочної кислоти. Найбільше накопичення молочної кислоти було зафіксовано в дослідному зразку (на 5,3\%), порівняно $з$ контролем.

Кількісний вміст молочної кислоти вплинув на показник активної кислотності. У дослідному зразку величина рН була нижчою, ніж в контрольному варіанті (рис. 2).

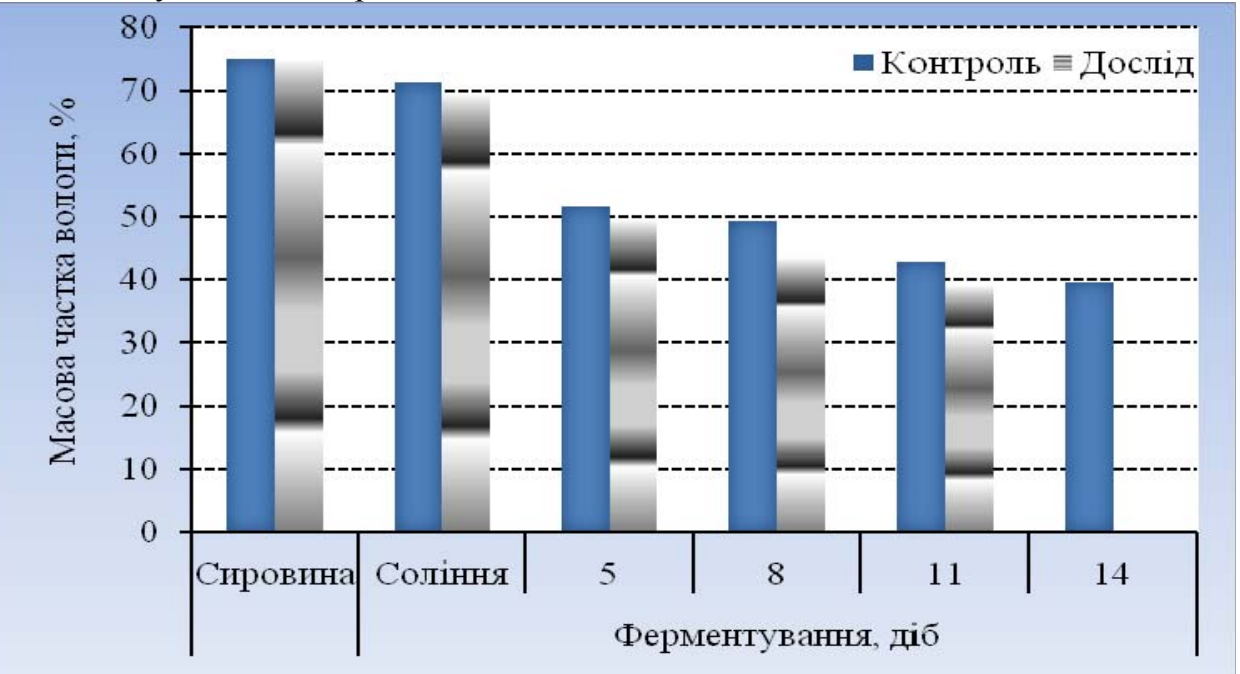

Рис. 1. Динаміка зміни масової частки вологи під час виготовлення виробів

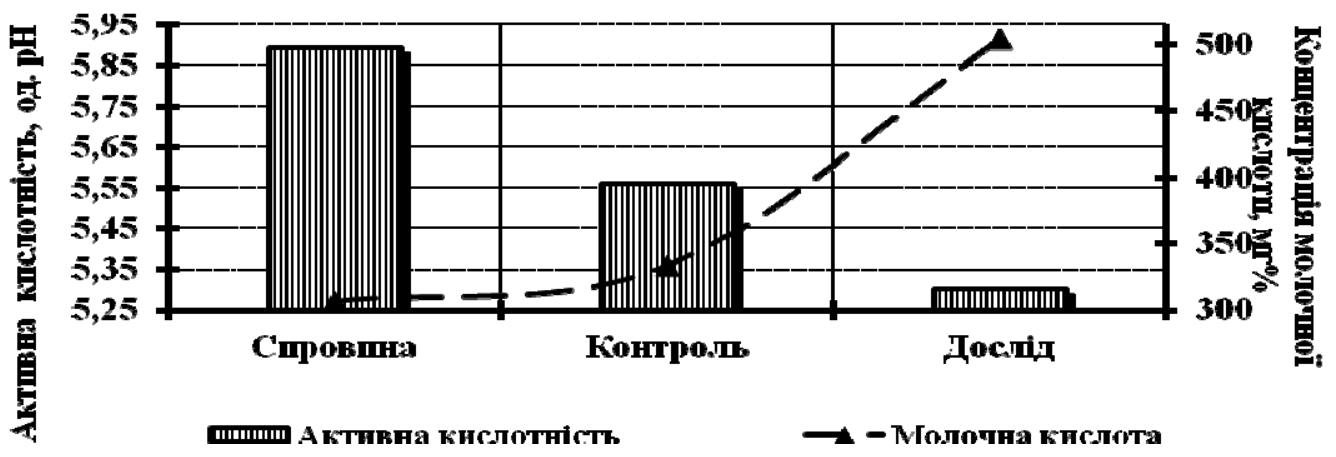

Рис. 2. Зміна показника рН і вмісту молочної кислоти в готових продуктах

Важливим показником дозрівання ферментованих продуктів є вміст вільних амінокислот, що утворюються в процесі дозрівання продукту. Відомо, що вільні амінокислоти впливають на формування характерного смаку готового продукту. Встановлено, що бактеріальний препарат специфічно впливав на якісний і кількісний склад вільних амінокислот в готовому продукті (рис. 3).

На 11 добу дозрівання в дослідному продукті, незамінних амінокислот накопичувалося більше в
1,5 раза, замінних амінокислот - в 1,4 раза, порівняно 3 контролем. Відомо, що збільшення вмісту амінокислот $\epsilon$ свідченням підвищення біологічної цінності продуктів (рис. 3).

Готовий продукт із бактеріальним препаратом «ЛРР» порівняно 3 контролем містить більше вільних амінокислот, які формують специфічний м'ясний смак, а саме: глютамінової кислоти, лізину, фенілаланіну, аланіну, ізолейцину, метіоніну, треоніну і серину. 


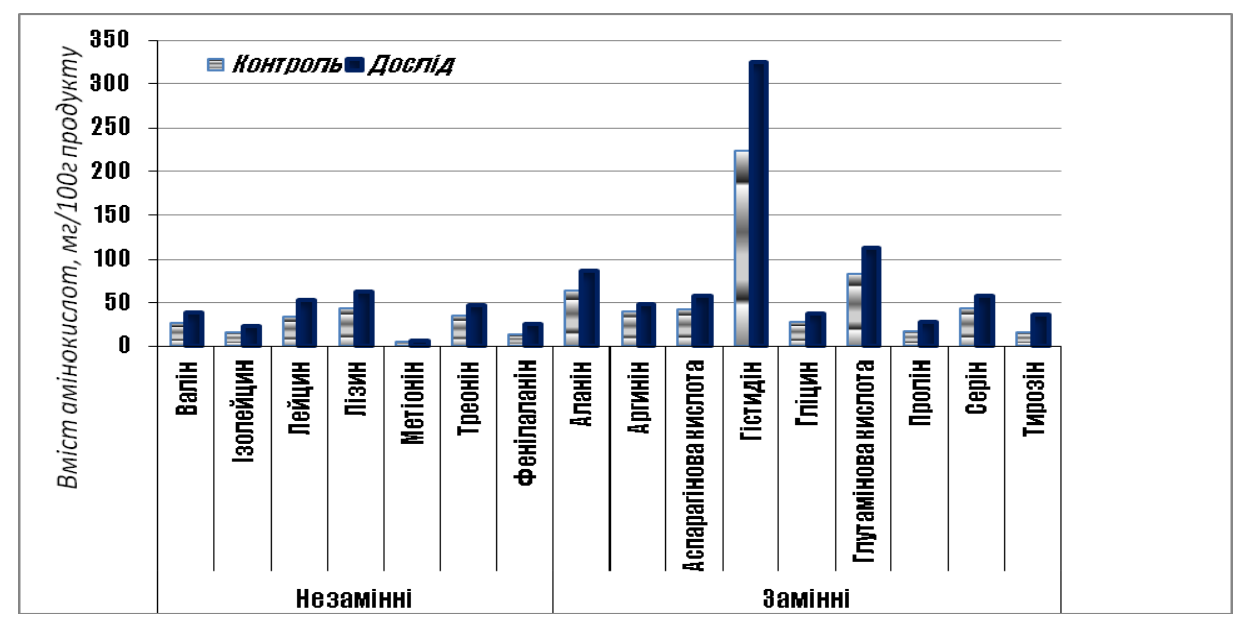

Рис. 3. Склад вільних амінокислот у делікатесних продуктах із птиці

Смак і аромат продуктів обумовлюють також леткі жирні кислоти, що утворюються в результаті гідролітичного і окиснювального розщеплення біохімічних з'єднань м'ясної сировини і прянощів.

Накопичення загального вмісту летких жирних кислот активно відбувалося в дослідному продукті, в

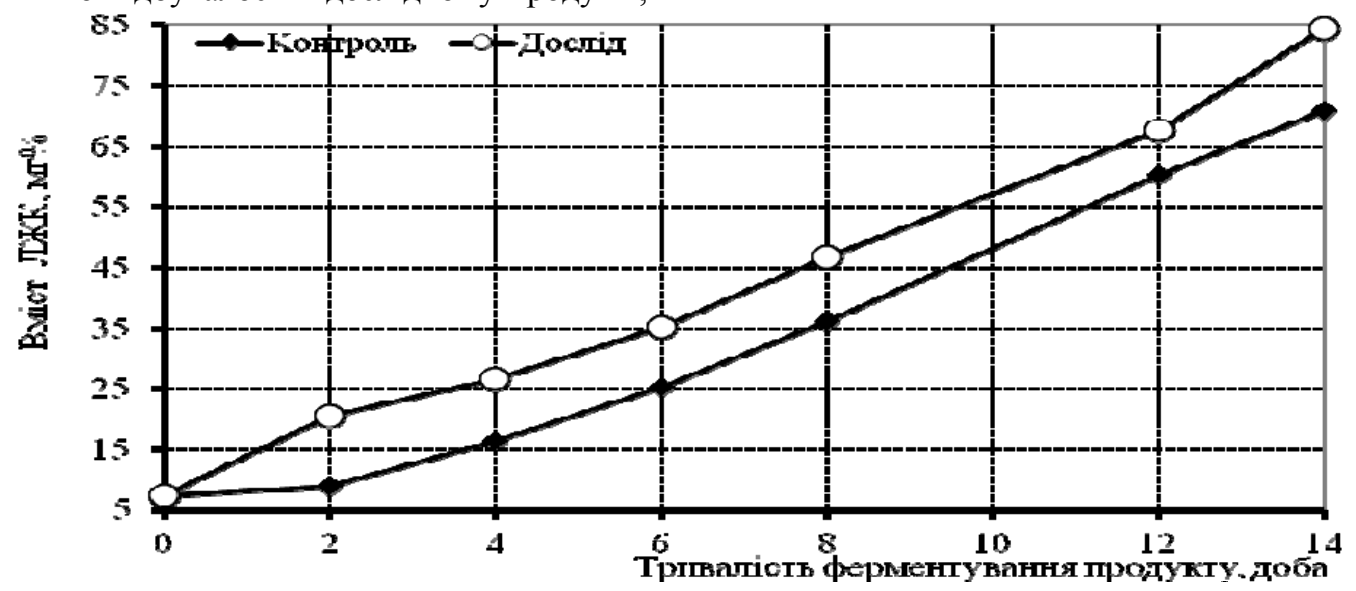

Рис 4. Накопичення летких жирних кислот в делікатесному продукті з філе курчат-бройлерів протягом дозрівання
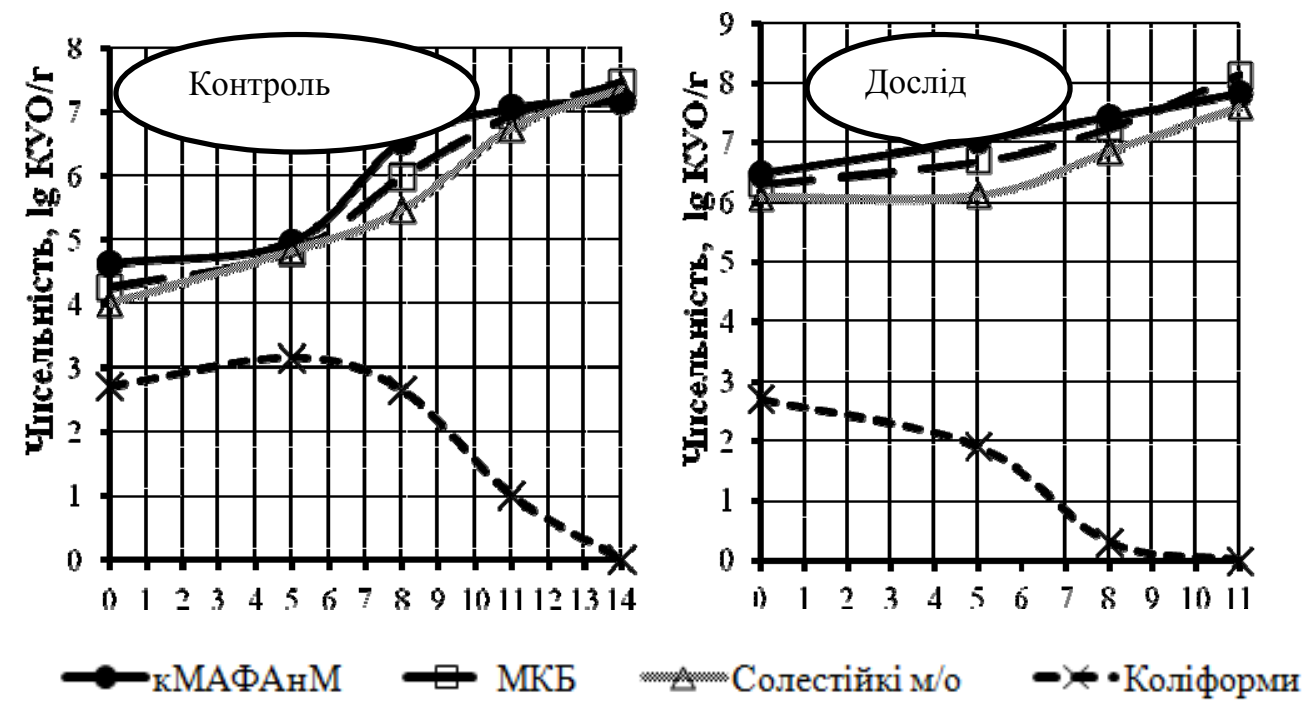

Рис. 5. Динаміка розвитку мікрофлори зразків делікатесних продуктів 


\section{Висновки}

Впродовж технологічного процесу було досліджено динаміку змін якісних показників делікатесного продукту. Встановлено, що додавання до м'яса птиці бактеріального препарату забезпечує бажаний перебіг фізико-хімічних, біохімічних та мікробіологічних перетворень м'ясної сировини. Застосування використаного в технології бактеріального препарату «ЛРР» та інгредієнтів рецептури забезпечує інтенсивне зниження масової частки вологи, величини $\mathrm{pH}$, збільшує накопичення молочної кислоти та пригнічує розвиток небажаних мікроорганізмів, що в сукупності сприяє інтенсифікації технологічного процесу виробництва делікатесного сиров'яленого продукту.

Перспективи подальших досліджень. В подальших дослідженнях планується визначити жирнокислотний склад продукту та його реологічні характеристики.

\section{Бібліографічні посилання}

Preparaty bakterialni dlia vyrobnytstva fermentovanykh miasnykh produktiv. Tekhnichni umovy : TU U 15.500419880-101-2010. [Chynnyi vid 2010-03-01]. K.: Ukrmetrteststandart, 2010, 10 (in Ukrainian).

Aro-Aro, J.M., Nyam-Osor, P., Tsuji, K. (2010). The effect of starter cultures on proteolytic changes and amino acid content in fermented sausages. Food Chemistry. 119(1), 279-285.

Antipova, L.V., Glotova, I.A., Rogov, I.A. (2001). Metody issledovanija mjasa i mjasnyh produktov. M. : Kolos (in Russian).

Стаття надійшла до редакиії 1.03.2017 